\title{
Satisfaction and Expectation Analysis of Surabaya-Porong Commuter Line Users
}

\author{
Hera Widyastuti, Ahmad Soimun,and Anggit Lestari Putri
}

Abstract - The people of Sidoarjo who are doing the activities at Surabaya need a mode of transportation that can serve their mobility from home to their office and vice versa. To meet those need, it is necessary to provide a better transportation and quality that includes security, comfort, timely, efficient and connectivity. Train is one type of mode transport that can be used as an alternative to help overcome all those problems. The SurabayaPorong Commuterline is expected to attract the people of Sidoarjo in order to reduce the number of vehicles entering Surabaya and continuously, reduce congestion rate in Surabaya. But in the implementation of this commuter line is still not desirable by the public, this can be seen from the low occupancy of train (below 50\%) and the trend of the number of commuter train passengers from year to year. The amount is very small when compared with the number of private vehicles from the direction of Sidoarjo to the city of Surabaya. Therefore, there needs to be an analysis of the satisfaction and expectation commuter users. Data collection was conducted on questionnaire field survey of respondents which is used for analyzing the performance on the satisfaction and expectation of commuter users. Satisfaction and expectation of train users have analyzing using Customer Satisfaction (CS). The results of the analysis have shown that several priority factors expected be improved, frequency and air condition. Moreover, the alertness of the officer or train conductor need to be maintained

This paper is intended to develop Indonesian Driving Anger Scale by adopting several items of driving anger short scale developed by Deffenbacher et al in the USA. The respondents were asked to rate the amount of anger that would be provoked from none at all, a little, some, much and very much if the items in the questionnaire were actually happened. Respondents were 176 car drivers or motorcycle riders aged at least 17 years old and hold a valid driving license from Greater Jakarta. The proportion of respondents by gender was 116 males and 60 females. There were only 4 items trigger anger more than average (more than mean score 3.00), i.e.

H. Widyastuti is with the Department of Civil Engineering, Institut Teknologi Sepuluh Nopember, Surabaya,Indonesia

A. Soimun is with the Department of Civil Engineering, Institut

Teknologi Sepuluh Nopember, Surabaya,Indonesia

A. L. Putri is with the Department of Civil Engineering, Institut

Teknologi Sepuluh Nopember, Surabaya,Indonesia (e-mail :

anggitlestariputri@gmail.com). other driver yell at you rudely (3.90), someone weaving in and out of traffic (3.67), other driver drove very slowly in the fast lane and therefore slowing traffic (3.26) and someone backs right out in front of you without looking (3.68). Male respondents $(\mathbf{2 . 8 5})$ were significantly $(\alpha=0.003)$ more hot-tempered than female respondents (2.55) in terms of mean score of 14 items.

Index Terms - Commuter users, satisfaction an expectation, customer satisfaction Index (CSI).

\section{INTRODUCTION}

Ir $\mathrm{n}$ the development of the city of Surabaya is very rapidly so many people around Surabaya, especially Sidoarjo doing work activities to the city of Surabaya. Surabaya as the center of industrial, commercial and government activities in East Java, demanding people doing activities in the city of Surabaya. Sidoarjo people who do activities to the city of Surabaya need transportation that can serve their mobility. BPS of Surabaya recorded the number of population censuses in 2014 of 2,853,661 inhabitants. But in fact it during the day can increase to reach 5-6 million people. This shows the journey to the city of Surabaya is dominated by work activities, services and trade inhabitants around Surabaya city hinterland one of Sidoarjo regency which directly borders the city of Surabaya.

As for commuter trains Surabaya Sidoarjo frequency per day early 5 times it decrease in the number of passengers each year its PT. KAI as owner reduced the frequency of commuter trains Surabaya Sidoarjo to 3 times. An average daily passenger number in 2016 is 843. The amount is very small when compared with the number of private vehicles from the direction of Sidoarjo to the city of Surabaya. Below is the number of commuter train passengers in Surabaya Porong during 2015 and 2016, a significant decline in 2016.

The commuter train is expected to attract the people of Sidoarjo who will travel to reduce the number of vehicles entering the city of Surabaya so that it can reduce traffic congestion in the city of Surabaya. So it is necessary to also think about to improve the service schedule, headway and timeliness of commuter train Surabaya Porong. 
Other factors also need to be considered to find the best solution for the problems. So in the end to produce mass transit commuter trains Surabaya Porong which became the destination of transportation to travel from Surabaya Sidoarjo or vice versa. It also produces better performance. Travel of private vehicles can be reduced and can save travel time travel.

\section{LITERATURE REVIEW}

\subsection{Commuter Line}

Commuter Rail generally has slow characteristics in accelerating, so to achieve adequate service levels the distance between stations / shelters should be no less than $1.6 \mathrm{~km}$. Determination of location of station / shelter is closely related to the availability of a meeting point which is the gathering place of feeder vehicle (feeder) if the condition can be met then the distance between stations / shelter up to $4.8 \mathrm{~km}$ still fairly normal (Grava, 2002).

\subsection{Public Transportation Performance}

The magnitude of operating performance or service level of a public transport system can be seen from several parameters that can be used as a tool to see the effectiveness and efficiency of operating the number of fleets.

The parameters are load factor, travel speed, headway time, service time, and number of vehicles in operation. (Direktorat Jenderal Perhubungan Darat, 2002).

\subsection{Quality and Public Services}

The performance parameters of a public transport system established by the Directorate General of Land Transportation in 2002 are the speed and timing of service. The speed of travel is the time taken between shelters divided by the distance between the shelters. Good or bad quality is highly dependent on user judgment. Thus, service quality can be defined as the degree of discrepancy between what is expected and what is perceived. Service user satisfaction is the level a person feels has compared the perceived performance (result) with what is expected. There are 6 instruments that will be used for this research include:
a. Reliability
b. The Responsiveness
c. Assurance
d. Emphatic

e. Tangible

f. Accessibility (convenience)

\subsection{Importance Performance Analysis (IPA) Methods}

Quadrant analysis aims to perform mapping or perception and preferences of consumers / customers on some indicators of service quality that affect customer satisfaction. Based on the assessment of the importance and results of the work assessment, it will produce a calculation into a level of conformity between the level of importance and level of implementation. The level of conformity is the result of comparison of performance score with interest score. This level of conformity will determine the priority order of increasing the factors that affect customer satisfaction.

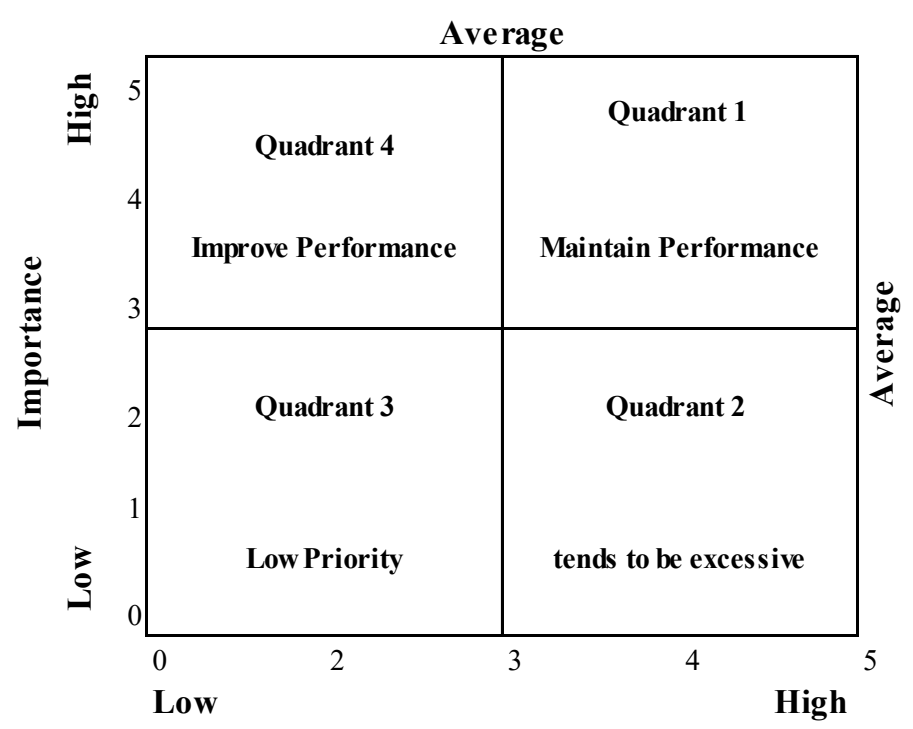

Satis faction

Fig.1. Importance-Performance Grid Cartesian Diagram

\subsection{Customer Satisfaction Index (CSI) Methods}

Customer Satisfaction Index (CSI) is done to find out customer satisfaction on delivery given by commuter line. The phases of calculating customer satisfaction index are:

1. Weighting Factors (WF)

$\mathrm{WF}=($ Median Score Level of importance $) /($ Total Median Score Level of importance)

2. Weighted Score (WS)

$\mathrm{WS}=\mathrm{WF} \times \mathrm{x}$ Median score level of performance 
3. Weighted Median Total (WMT)

$\mathrm{WMT}=\mathrm{WS}$ tot

4. Customer Satisfaction Index (CSI)

$\mathrm{CSI}=\mathrm{WMT} /$ (highest score level of performance)

5. Customer Satisfaction Index (CSI)

$0.81-1.00$ Very satisfied

$0.66-0.80$ Satisfied

$0.51-0.65$ Quite satisfied

$0.35-0.50$ Less satisfied

\section{Methodology}

Survey of research conducted by method of probability sampling method through convenience sampling that is with criterion of respondent that will be made subject of sample must be in research location and willing to be interviewed. Data collection was done by interviewing and distributing questionnaires of 140 respondents of Surabaya Porong commuter train users on weekdays and holidays. After data obtained then analyzed by Cartesius diagram method with Method of Importance Performance Analysis (IPA) and Customer Satisfaction Index (CSI).

\section{RESULT AND ANALYSIS}

\subsection{Attribute and characteristics}

TABLE I

ATTRIBUTE AND CHARACTERISTICS

\begin{tabular}{|c|c|c|}
\hline Attribute & Variable & Parameter \\
\hline 1 & \multirow{3}{*}{ RELIABILITY } & Ease of reaching station location \\
\hline 2 & & $\begin{array}{l}\text { Availability of information related to } \\
\text { commuting schedule }\end{array}$ \\
\hline 3 & & $\begin{array}{l}\text { Accuracy of commuting travel } \\
\text { schedule }\end{array}$ \\
\hline 4 & \multirow{2}{*}{ RESPONSIVENESS } & $\begin{array}{l}\text { Speed and readiness of officers in } \\
\text { providing services to customers to } \\
\text { complete }\end{array}$ \\
\hline 5 & & $\begin{array}{l}\text { Speed and accuracy of the officer in } \\
\text { providing information required } \\
\text { customers }\end{array}$ \\
\hline 6 & \multirow{3}{*}{ ASSURANCE } & Security on board and train ride \\
\hline 7 & & Comfort on board ride \\
\hline 8 & & $\begin{array}{l}\text { Availability of insurance or safety } \\
\text { guarantees }\end{array}$ \\
\hline 9 & \multirow[b]{2}{*}{ EMPHАТY } & Ticket prices are offered \\
\hline 10 & & $\begin{array}{l}\text { 24-hour customer } \\
\text { availability }\end{array}$ \\
\hline
\end{tabular}

$\begin{array}{ll}11 & \text { Cleanliness in the train } \\ 12 & \text { Cleanliness of the toilet on the train } \\ 13 & \text { Air circulation on the train } \\ 14 & \text { Availability of seats on the train }\end{array}$

\subsection{Performance of Commuter Railway Surabaya Porong or otherwise}

\subsubsection{Travel Time}

\section{1) Surabaya Porong Route}

For the analysis of commuter train travel time Surabaya Porong using data obtained from PT. KAI and also data that is done by direct survey from observation on train survey on commuter trains Surabaya Porong. The survey was conducted during 4 day trips and 4 afternoon trips and conducted on weekdays and during holidays. The intermediate time is obtained by the time of arrival of the train minus the time of departure at the previous station / stop. Up and down time is obtained by subtracting the departure time by arrival time at the same station.

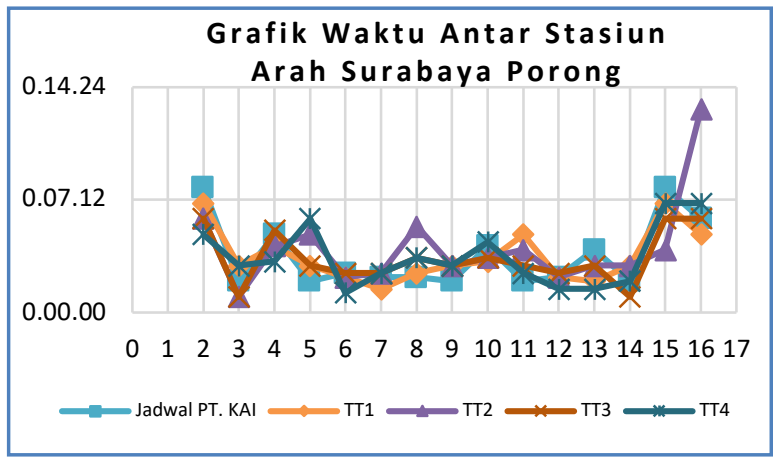

Fig 2. Time Traveling between Commuter Train Station Surabaya Porong (Surabaya Porong Route).

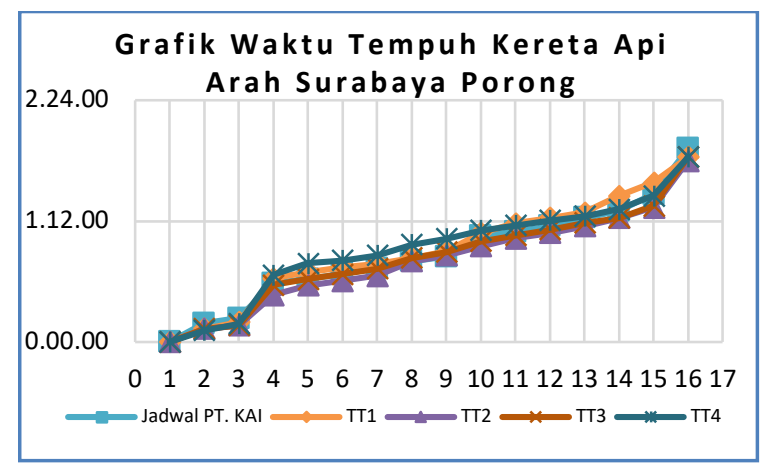

Fig. 3. Commuter Traffic Time Surabaya Porong (Surabaya Porong Route) Source: Analysis 
From Fig. 2 can be seen the average travel time of the station / bus stop. It can be seen that the average travel time for the commuter train Surabaya Porong during the day is:

Fastest TT $=\frac{\mathrm{TT} \min 1+\mathrm{TT} \min 2+\mathrm{TT} \min 3+\mathrm{TT} \min 4}{4}=$ $\frac{90 \text { second }+60 \text { second }+60 \text { second }+75 \text { second }}{4}=72$ second $=1$ minute 12 second

It can be seen that the average travel time for the commuter train Surabaya Porong during the day is:

$\begin{array}{lll}\text { Travel Time } & = & \text { TT1+TT2+TT3+TT4 } \\ \frac{110 \text { minute }+105 \text { minute }+105 \text { minute }+110 \text { minute }}{4}= & 108\end{array}$ minute atau 1 hour 48 minute

The direct survey of the average travel time for commuter trains Surabaya Porong in the afternoon is 1 hour 48 minutes. Meanwhile, according to PT. KAI is 1 hour 55 minutes.

\section{2) Rute Porong - Surabaya}

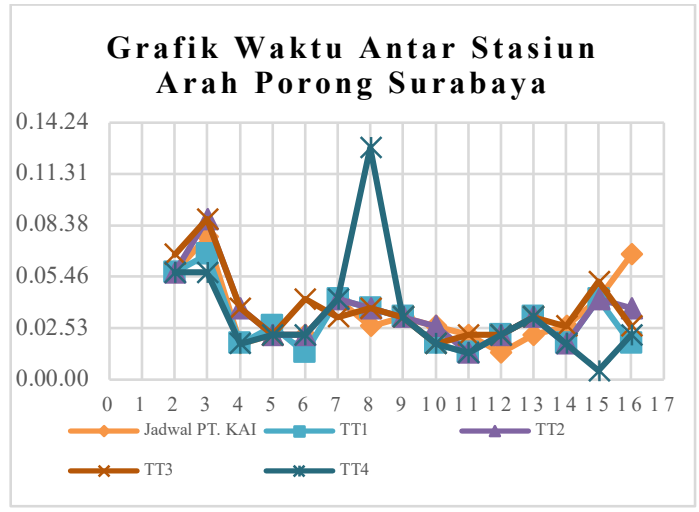

Fig. 4. Travel Time between Commuter Train Station Surabaya Porong (Porong Surabaya Route).

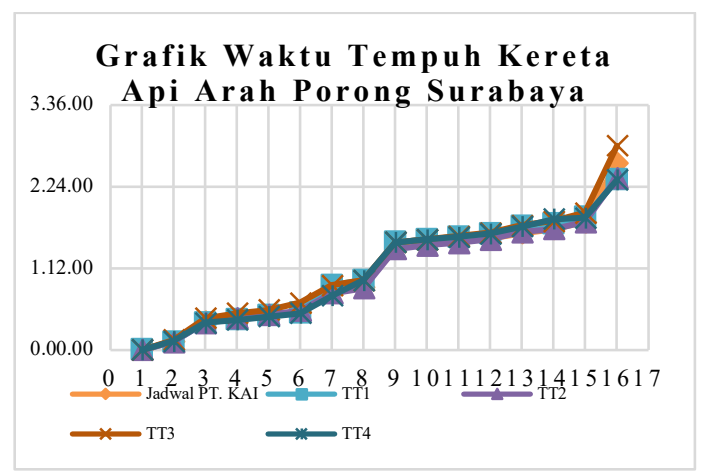

Fig. 5. Commuter Train Time Surabaya Porong (Porong Surabaya Route)
From the graph can be seen the average travel time of the station / bus stop to other stations for travel time 1,2,3 and 4 on the commuter trains Surabaya Porong Porong route Surabaya are:

Fastest TT $=\frac{\text { TT } \min 1+\mathrm{TT} \min 2+\mathrm{TT} \min 3+\mathrm{TT} \min 4}{4}=$ $\frac{90 \text { second }+90 \text { second }+120 \text { second }+30 \text { second }}{4}=83$ Second $=1$ minute 13 second.

From the picture Can be seen the average travel time for commuter trains Surabaya Porong is

$\begin{array}{lrr}\text { Travel time }= & \frac{\text { TT1+TT2 }+ \text { TT3 }+ \text { TT4 }}{4} \\ \frac{150 \text { minute }+152 \text { minute }+180 \text { minute }+150 \text { minute }}{4} & = & 158\end{array}$ minute or 2 hour 38 minute.

Directly the average travel time for commuter trains Surabaya Porong in the afternoon is 2 hours 38 minutes. Meanwhile, according to PT. KAI is 2 hours 45 minutes.

\section{1) Headway}

Departure time between trains (headway) is the hose of the first train arrival with the next train on a route and time. For commuter train Surabaya Porong when the difference between trains about 5 hours in the morning, 45 minutes in the afternoon and afternoon, this is because the frequency of commuter trains Surabaya Porong is 3 times round trip every day.

\section{2) Load Factor}

Load factor analysis on commuter trains Surabaya Porong viewed from each station / stop. Stages of calculation of load factor on trains per station / bus stop is Do on train survey to get the number of the number of passengers up and down on each station / stop. To get the load factor then divide between the volume of train passengers with the capacity of the train in a series of trains. For the same.

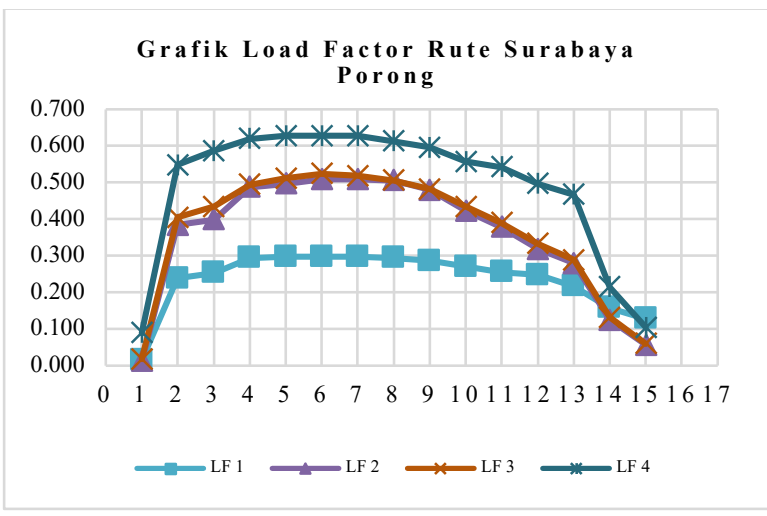

Fig. 6. load factor commuter railway Surabaya Porong Surabaya route station Porong 


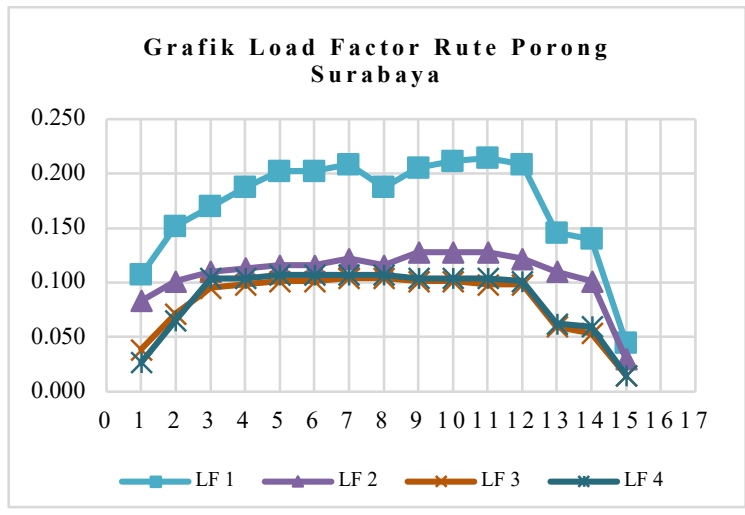

Fig. 7. load factor commuter railway Surabaya Porong station Porong Surabaya

From the survey results Load factor commuter trains Surabaya Porong no one up to number 1 so load factor commuter train can still accommodate passengers.

\section{3) Analysis Satisfaction and IPA Expression} (Importance and Performance Analysis

The results of calculations at the level of conformity are further translated into four parts or quadrant Cartesian diagram It is intended to derive a point on the diagram based on the level of satisfaction and expectation that allows the author to categorize and prioritize efforts to improve attributes that are really considered important and expected by the customer to obtain maximum satisfaction. The position of each attribute in the four quadrants is used as an alternative strategy tool to increase customer satisfaction of commuter train Surabaya Porong. Cartesian diagram graphs also show the position of each attribute affecting the customer satisfaction of the commuter train Surabaya Porong in their respective quadrants. Interpretation of Importance and Performance Analysis is described as follows

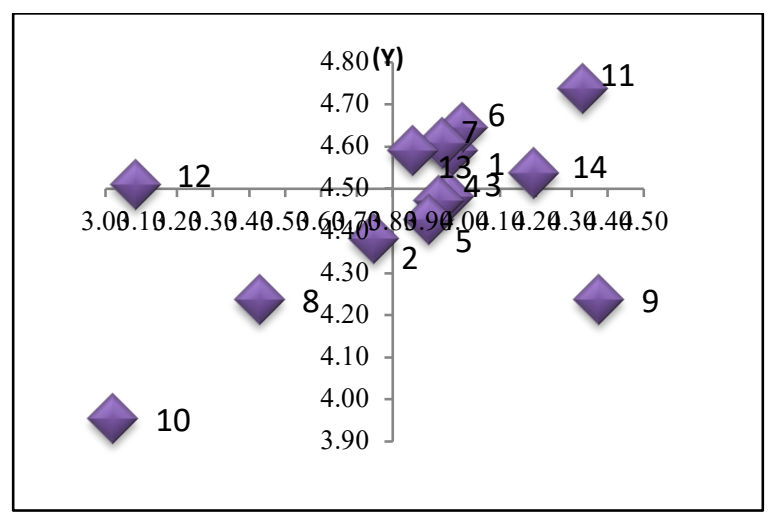

Fig. 8. Cartesius Diagram Importance Performance Analysis (IPA)
Fig. 8 shows that the $\mathrm{X}$ and $\mathrm{Y}$ axes, where $\mathrm{X}$ axis is the average value of satisfaction and $\mathrm{Y}$ axis is the average value of expectation. The location of the attribute is divided into 4 quadrants where each quadrant has its own meaning.

1. Quadrant 1 "Maintain Performance"

Quadrant 1 shows attribute attributes that need to be maintained and its existence. The attribute according to the customer is so good that the customer is satisfied.

1) Ease of reaching station location (attribute 1)

2) Security on board and train ride (attribute 6)

3) Comfort on board ride (attribute 7)

4) Ticket prices are offered (attribute 9)

5) Cleanliness in the train (attribute 11)

6) Air circulation on the train (attribute 13)

7) Availability of seats on the train (attribute 14)

2. Quadrant 2 shows attributes that are perceived to perform well so that customers perceive the perceived performance is excessive. The attributes are still carried out but must be seen and in according to the level of expectation so as not to cause excessive effects Attributes included in this quadrant are:

1) Accuracy of commuting travel schedule (attribute 3)

2) Speed and readiness of officers in providing services to customers to complete (attribute 4)

3) Speed and accuracy of the officer in providing information required customers (attribute 5)

\section{Quadrant 3 "Low Priority"}

In quadrant 3 is an attribute that is considered less attention so that customers feel unnoticed desire about the attribute. Attribute attributes included in quadrant 3 are:

1)Availability of information related to commuting schedule (attribute 2)

2) Availability of insurance or safety guarantees (attribute 8)

3)24-hour customer service availability (attribute 10)

4. Quadrant 4 "Improve Performance"

In quadrant 4 should be prioritized and improved, so that performance increases and becomes better, because these attributes have a high expectation value for customers, but its performance is still less:

1) Cleanliness of the toilet on the train (attribute 12)

For that input that can be given is that commuter rail is necessary to improve performance, service if need to be improved again for performance improvement is 
still lacking. Evaluation and improvement actions that need to be improved are:

- Frequency schedule

- Use of toilet

- Procurement of Air Conditioner

- At every bus stop there is a swift official with the help ladder in each carriage

- Improved Infrastructure Stop area

\section{4) Customer Satisfaction Index (CSI) Methods}

TABLE I

CUSTOMER SATISFACTION INDEX RESUlTS

\begin{tabular}{ccccc}
\hline Attribute & $\begin{array}{c}\text { Median } \\
\text { score }\end{array}$ & $\begin{array}{c}\text { Importance } \\
\text { Weighting } \\
\text { Factor } \\
\text { (WF) }\end{array}$ & $\begin{array}{c}\text { Median } \\
\text { Score of } \\
\text { Performance }\end{array}$ & $\begin{array}{c}\text { Weighted } \\
\text { Score } \\
\text { (WS) }\end{array}$ \\
\hline 1 & 4,59 & 0,073 & 3,96 & 0,29 \\
2 & 4,38 & 0,070 & 3,75 & 0,26 \\
3 & 4,48 & 0,071 & 3,95 & 0,28 \\
4 & 4,47 & 0,071 & 3,93 & 0,28 \\
5 & 4,43 & 0,070 & 3,90 & 0,27 \\
6 & 4,65 & 0,074 & 3,99 & 0,29 \\
7 & 4,61 & 0,073 & 3,94 & 0,29 \\
8 & 4,24 & 0,067 & 3,43 & 0,23 \\
9 & 4,71 & 0,075 & 4,37 & 0,33 \\
10 & 3,95 & 0,063 & 3,02 & 0,19 \\
11 & 4,74 & 0,075 & 4,33 & 0,33 \\
12 & 4,51 & 0,072 & 3,08 & 0,22 \\
13 & 4,59 & 0,073 & 3,85 & 0,28 \\
14 & 4,54 & 0,072 & 4,19 & 0,30 \\
TOTAL & 62,88 & 1,00 & 53,69 & 3,85 \\
(WMT) & & & & \\
Weighted & & & 3,85 & \\
Average & & & & \\
& Customer satisfaction Index (CSI) & & \\
\hline & & & & \\
\hline
\end{tabular}

\section{Conclusions}

From the general performance of commuter railway Surabaya Porong after comparing schedule time of PT. KAI and direct survey time commuter train performance is in accordance with the schedule. From SK Dirjen 687/2020 and Directorate General of Land Transportation in 2002 which discussed the standard of urban public transport service, commuter train Surabaya Porong in terms of waiting time, length of travel, Load factor, head way, travel time already fulfilling public transport service properly. Characteristics of commuter train passengers Surabaya Porong is a woman with the aim of working always using commuter train Surabaya Porong on the day of work. The transportation that commuter train users use to get to the station / commuter train stops is good to come and leave is a motorcycle. In terms of satisfaction and expectations of commuter railway users Porong Surabaya many need to be addressed from the side of facilities such as Toilet damage, the absence of CCTV, and air circulation in commuter trains are minimal need for air conditioner. From the side of the officer satisfaction and ticket prices is very good and expected to be maintained for air conditioner. From the side of the officer satisfaction and ticket prices is very good and expected to be maintained.

\section{REFERENCES}

[1] Amirin, T. M., "Populasi dan sampel penelitian 4: Ukuran sampel rumus Slovin," 2011, Retrieved 01 24, 2016, from tatangmanguny.wordpress.com.

[2] Bappeko, "RTRW Kota Surabaya :Badan Pusat Statistika, 2016.

[3] Direktorat Jenderal Perhubungan Darat, "Surat Keterangan Direktorat Jenderal Perhubungan Darat Tentang Pedoman Teknis Penyelenggaraan Angkutan Penumpang Umum di Wilayah Perkotaan Dalam Trayek Tetap Dan Teratur," Jakarta, 2015.

[4] Grava, S., "Urban Transportation Systems, McGraw - Hill, New York, 2002.

[5] Ofyar Z, Tamin, "Perencanaan dan Pemodelan Transportasi, ITB, Bandung, 2000.

[6] Putri, Maharani Ajeng, and Widyastuti Hera, "Evaluasi Kinerja Dan Tingkat Kepuasan Pengguna Moda Transportasi Kereta Api Rapih Dhoho (Blitar-Surabaya)," Tugas Akhir Jurusan Teknik Sipil, Institut Teknologi Sepuluh Nopember, Surabaya, 2016.

[7] Rosida S, Bayu, and Herijanto Wahyu, "Analisis Kinerja Operasional Kereta Api Sriwedari Ekspress Jurusan Solo Yogya," Jurnal Tugas Akhir Jurusan Teknik Sipil, Institut Teknologi Sepuluh Nopember, Surabaya, 2014.

[8] Setiawan, Rudy, "Karakteristik Pengguna Kereta Api Komuter Surabaya-Sidoarjo," Fakultas Teknik Sipil \& Perencanaan Jurusan Teknik Sipil Universitas Kristen Petra Surabaya, 2005.

[9] V. R. Vuchic, "Urban Pubic Transportation: Systems and Technology," New Jersey, 1981. 